Journal of Advanced Research in Applied

Sciences and Engineering Technology

Journal homepage: www.akademiabaru.com/araset.html ISSN: 2462-1943

\title{
COVID-19 Outbreak in Malaysia: Investigation on Fatality
}

Cases

\author{
Nor Aishah Ahad ${ }^{1,}{ }^{*}$, Friday Zinzendoff Okwonu ${ }^{1,2}$, Pang Yik Siong ${ }^{1}$ \\ School of Quantitative Sciences, College of Arts and Sciences, Universiti Utara Malaysia, 06010 UUM Sintok, Kedah, Malaysia \\ School of Basic Sciences, Nigeria Maritime University, Kurutie Campus, Delta State, Nigeria
}

\section{ABSTRACT}

The COVID-19 pandemic has affected the lives of millions across the globe and taken away hundreds of thousands of lives. The spread of COVID-19 due to negligence had caused thousands of confirmed cases in Malaysia. Malaysia Government enforced Movement Control Order as a measure to prevent further outbreak of the disease. This study investigated the current situation of COVID-19 in Malaysia and patients' demographical connections to the disease. The findings show that COVID-19 attacked males more than females and the elderly of sixty years and above are mostly affected.

Keywords:

COVID-19, Malaysia, gender, age,

fatality, IS-FMTS

Copyright @ 2020 PENERBIT AKADEMIA BARU - All rights reserved

\section{Introduction}

In December 2019, an outbreak of a mysterious pneumonia of unknown origin was reported in Wuhan, Hubei Province, China. Most of these cases were epidemiologically linked to the Huanan Seafood Wholesale Market [1, 2]. The initial outbreak was reported in the market in December 2019 and involved about $66 \%$ of the staff there. The market was shut down on January 1, 2020, after the announcement of an epidemiologic alert by the local health authority on December 31, 2019. However, in January, thousands of people in China, including many provinces (such as Hubei, Zhejiang, Guangdong, Henan, Hunan, etc.) and cities (Beijing and Shanghai) were attacked by the rampant spreading of the disease [3]. One of the reasons may be due to the heavy transportation load during the Chinese Lunar New Year (on January 25) period [4]. The disease spread to other countries outside China. The first exported case outside China was in Thailand on January 13, 2020. However, the disease spread rapidly and globally. Not only familial clusters but also outbreaks in ocean liners and international conveyance were reported.

The disease was officially named Coronavirus Disease-2019 (COVID-19) by World Health Organization (WHO) on February 11, 2020. Coronavirus disease 2019 (COVID-19) is defined as an illness caused by a novel coronavirus formerly named as the 2019 novel coronavirus (2019-nCoV),

\footnotetext{
* Corresponding author.

E-mail address: aishah@uum.edu.my

https://doi.org/10.37934/araset.20.1.110
} 
now called severe acute respiratory syndrome coronavirus 2 (SARS-CoV-2) [5]. It was initially reported to the World Health Organization on December 31, 2019. On January 30, 2020, World Health Organization declared the COVID-19 outbreak a global health emergency $[6,7]$. The World Health Organization declared COVID-19 as a global pandemic on the 11th March 2020 [8,9]. On the 13th March 2020, the World Health Organization announced that Europe was now the "epicentre" for the global coronavirus pandemic [10]. By the 31st July 2020, there was a cumulative figure of $17,106,007$ confirmed cases and 668,910 deaths reported to the World Health Organization [11]. Within seven months, the virus had spread like wildfire affecting all continents. The COVID-19 pandemic is straining not only the health systems of many countries but also the economies worldwide. Most countries are still grappling, and some are struggling with the problem [9].

At present, the exact mechanism of transmission of SARS-CoV-2 is still not completely understood. Human-to-human transmission via droplets is the main route of transmission within a susceptible population [12]. The novel coronavirus is primarily transmitted between people through respiratory droplets and contact transmission $[4,13,14]$. The infection is acute without any carrier status. Symptoms usually begin with nonspecific syndromes, including fever, dry cough, and fatigue. Multiple systems may be involved, including respiratory (cough, shortness of breath, sore throat, rhinorrhea, hemoptysis, and chest pain), gastrointestinal (diarrhea, nausea, and vomiting), musculoskeletal (muscle ache), and neurologic (headache or confusion). More common signs and symptoms are fever, cough, and short of breath [1,15].

It is crucial to know the incubation period of SARS-CoV-2 infection because it is the key to implementing control measures and surveillance. COVID-19 has a mean incubation period of 5.2 days (95\% confidence interval, 4.1-7.0) [16]. It has been estimated that the median incubation period is 5.1 days $(95 \% \mathrm{Cl}, 4.5-5.8)$, and $97.5 \%$ of the infected subjects will develop symptoms within 11.5 days $(95 \% \mathrm{Cl}, 8.2-15.6)$ of infection. Based on these estimates, it can be assumed that 101 out of 10,000 cases will develop symptoms after 14 days of observation or quarantine [17]. These estimates are consistent with those of other studies that reported a mean incubation period of 6.4 days (95\% credible interval: 5.6-7.7), ranging from 2.1 to 11.1 days (2.5th to 97.5 th percentile) [18] or 5.2 days (95\% Cl, 4.1-7.0), with the 95th percentile of the distribution at 12.5 days [16]. Thus, 14-day monitoring is advised following contact with a probable or confirmed SARS-CoV-2 case [19].

COVID-19 spread in Malaysia. The first case in Malaysia was reported on the $25^{\text {th }}$ January 2020 [20]. On the $15^{\text {th }}$ February 2020, the number of cases had escalated to 22 [21]. There were no new cases reported for 11 days until on the $27^{\text {th }}$ February 2020. This date marked the beginning of the second wave of coronavirus infection [22]. By $17^{\text {th }}$ March 2020, the first Malaysia in-border COVID19 death was recorded [23]. The number of cases increasing every day until $18^{\text {th }}$ March 2020 when a total of 790 cases had been reported [24]. To help curtail the spread of COVID-19 virus, the government of Malaysia initiated the Movement Control Order (MCO), effective on 18 March 2020, in order to increase social distancing and slow down the transmission rate of the virus [25]. The first phase of the MCO, which was introduced to break the chain of COVID19 infection, was from March $18^{\text {th }}$ to $31^{\text {st }}$. On $25^{\text {th }}$ March 2020, the Prime Minister of Malaysia announced the second phase of MCO from April $1^{\text {st }}$ to $14^{\text {th }}$. On Friday $10^{\text {th }}$ April, the Prime Minister announced the extension of the MCO (third phase) from April $15^{\text {th }}$ to $28^{\text {th }}$ [26]. On $23^{\text {rd }}$ April, the Prime Minister announced the fourth phase of MCO from 29 April extended until 12 May [27]. On the $13^{\text {th }}$ of May, Malaysia moved into the Conditional Movement Control Order (CMCO) until $9^{\text {th }}$ June. Currently, on $7^{\text {th }}$ June, the Prime Minister announced that Malaysia moved into the Recovery Movement Control Order (RMCO) initiated from $10^{\text {th }}$ June until $31^{\text {st }}$ August. All phases of movement control order implemented are shown in Table 1. 
Table 1

Phases of Movement Control Order (MCO) in Malaysia

\begin{tabular}{|c|c|c|c|}
\hline \multirow{2}{*}{ Movement Control Order (MCO) } & \multicolumn{2}{|c|}{ Duration } \\
\cline { 2 - 4 } & Phase 1 & Start Date & 18 March 2020 \\
\cline { 2 - 4 } MCO & Phase 2 & 1 April 2020 & 31 March 2020 \\
\cline { 2 - 4 } & Phase 3 & 15 April 2020 & 28 April 2020 \\
\cline { 2 - 4 } & Phase 4 & 29 April 2020 & 12 May 2020 \\
\hline \multicolumn{2}{|c|}{ Conditional MCO } & 13 May 2020 & 9 June 2020 \\
\hline \multicolumn{2}{|c|}{ Recovery MCO } & 10 June 2020 & 31 August 2020 \\
\hline
\end{tabular}

By the $31^{\text {st }}$ July 2020, Malaysia recorded a cumulative figure of 8,976 confirmed cases with 125 deaths [28]. COVID-19 cases in Malaysia included: Imported cases from overseas, cases close contacts of locally confirmed cases, community-acquired cases where the source of the infection is known (example, the Tabligh gathering cluster), or unknown [9]. The majority of those who are infected with COVID-19 have a self-limiting infection and do recover. The total cumulative number of cases fully recovered from COVID-19 and discharged from the ward was 8,644 cases ( 96.3 percent of total cases) [28]. However, a minority go on to suffer more severe disease and requiring intensive care unit admission.

Covid-19 virus infects all age brackets [29]. Older adults are at a significantly increased risk of severe disease following infection from COVID-19 [30]. Older people or elderly are classified as those who are sixty years old and above [31]. People of sixty years and above are mostly affected with respect to severity of illness [32,33]. Many deaths occurred in individuals who had at least one underlying co-morbidity, in particular those with cardiovascular diseases/hypertension and diabetes, but also with a range of other chronic underlying health conditions. Some of the reasons older people are greatly impacted by COVID-19 include the physiological changes associated with aging, decreased immune function, and multimorbidity which expose older adults to be more susceptible to the infection itself and make them more likely to suffer severely from COVID-19 disease and more serious complications [30]. People with medical conditions such as cardiovascular disease, cancer, diabetes, and chronic respiratory diseases are at high risk. Majority of the studies has shown that Covid-19 invaded male population than female [29,34].

In this paper, we want to investigate the situation of COVID-19 in Malaysia especially on case fatality ratio as of $31^{\text {st }}$ July 2020 , and the association between age, gender, and health condition towards the fatality of COVID-19 patient. The rest of this paper is organized as follows: Section Two discusses the materials and methods while Section Three consist of results and discussion. The conclusion is mentioned in Section Four.

\section{Methodology}

Ministry of Health of Malaysia ( $\mathrm{MOH}$ ) had been updating the latest Coronavirus Disease 2019 (COVID-19) statistics in Malaysia in their official portal [35]. The data for this study was collected from $25^{\text {th }}$ January to $31^{\text {st }}$ July 2020. This represents 189 days of COVID-19 outbreak in Malaysia. The number of deaths related to COVID-19 was recorded for every case. The data contain information such as case number, nationality, gender, age, the state in which the patient is receiving treatment, date of admission, date and time of deceased, and status of medical conditions [36]. The status of medical condition shows whether the patient of COVID-19 was healthy or has a health problem such as cardiovascular disease, cancer, diabetes, chronic respiratory diseases, and others. This section focuses on case fatality ratio, descriptive statistics, and graphical analysis of the data set to answer 
the aim of this study as stated in Section One. The hypothesis statements to be tested at $5 \%$ level of significance are:

1) mean age for male that involve in fatality is greater than female patient

2) mean age for male that involve in fatality with health complications is less than female patients.

Cumulative case fatality ratio (CFR) is defined as the sum of all deaths divided by the number of confirmed cases as shown in Equation (1).

$$
C F R=\frac{\sum_{i=1}^{k} D_{i}}{\sum_{i=1}^{N} C_{i}}
$$

Where $D_{i}$ (number of deaths that occur per day) and $C_{i}$ (number of confirmed cases per day).

\section{Results}

To date ( $31^{\text {st }}$ July 2020), Malaysia recorded a cumulative figure of 8,976 confirmed cases with 125 deaths [28]. The recovery rate for Malaysia is 96.3 percent. Malaysia declared two waves of COVID-19. The first wave starts when Malaysia recorded the first case on January $25^{\text {th }}, 2020$ and ended on February $16^{\text {th }}, 2020$. The second wave begins on February $27^{\text {th }}, 2020$ to date. Figure 1 shows the current situation of COVID-19 in Malaysia based on the number of confirmed cases, recovered, and deaths [37].

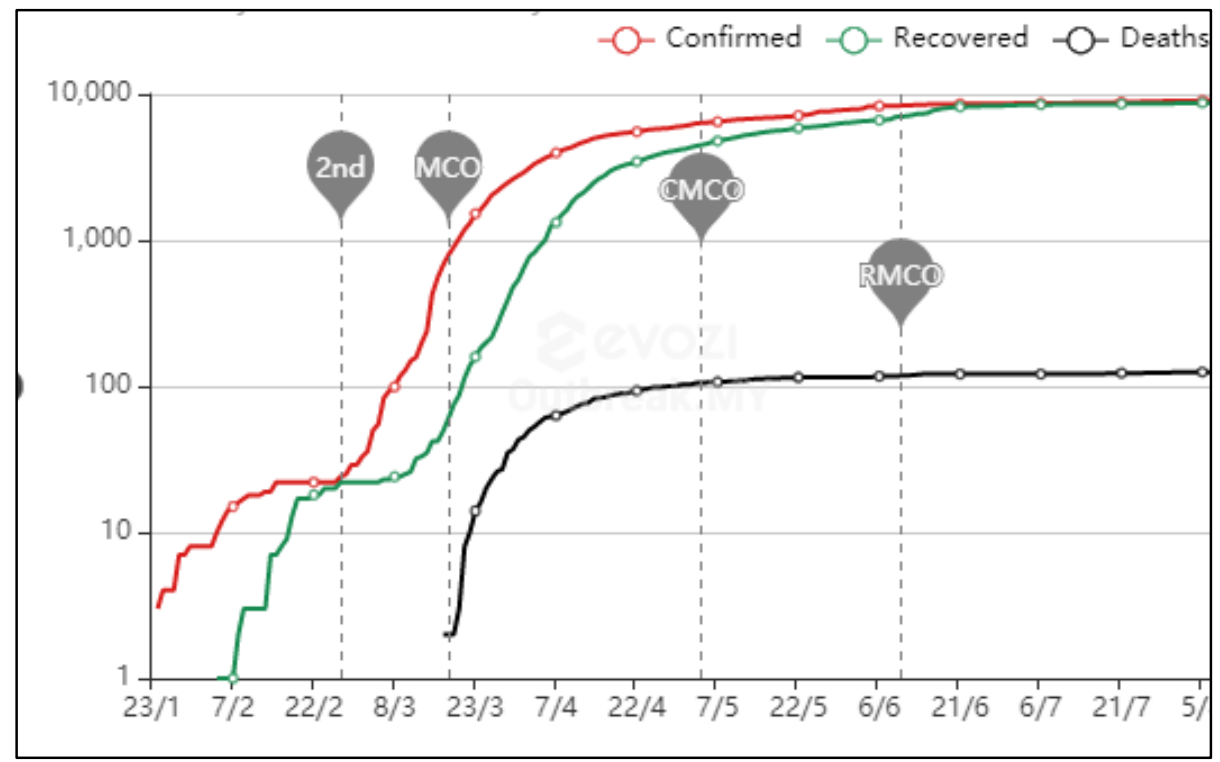

Fig. 1. Current situation of COVID-19 in Malaysia [37]

Figure 2 shows daily cases of COVID-19 in Malaysia during the MCO, CMCO, and RMCO based on new cases, discharged, and deaths [38]. During the first phase of $\mathrm{MCO}$, the number of new cases continue increasing every day with a low number of discharged. The second phase of the MCO shows that the number of new cases slowly decreases while discharged number show increment. The third and fourth phases of MCO reveals that the number of new cases decreases drastically while the discharged number exceeds the new cases. During the $\mathrm{CMCO}$, the number of new confirmed cases increase mostly due to imported cases from overseas. The beginning of RMCO reveals that the 
number of new confirmed cases are low while recovery cases are very high. Until the end of the duration, the number of confirmed cases is low. Observation from this trend shows that implementation of the movement control order is the right strategy to break the chain of infection and flattening the pandemic curve.

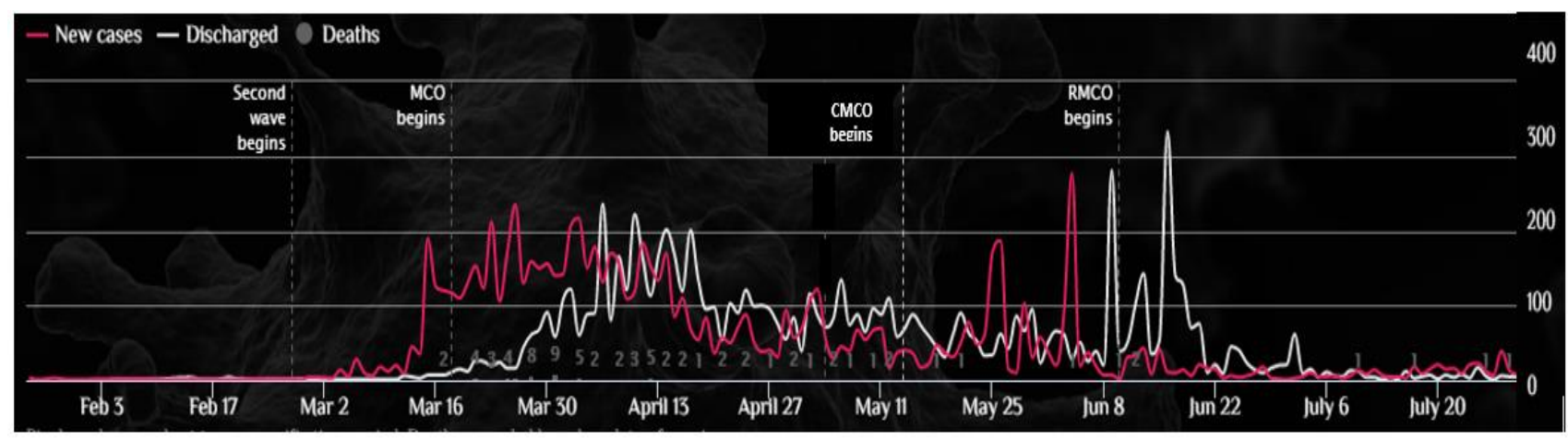

Fig. 2. Daily cases of COVID-19 in Malaysia [38]

As at $31^{\text {st }}$ July 2020 , the number of confirmed cases is 8,976 , discharged cases is 8,644 representing $96.3 \%$ recovering, active cases is 207 , and 125 death cases representing the cumulative case fatality ratio (CCFR) of 1.39\%. Figures 3 and 4 represent daily and cumulative CFR for COVID-19 in Malaysia for 189 days of the outbreak. Daily CFR for Malaysia was highest on the $140^{\text {th }}$ days while the cumulative CFR was highest on the $67^{\text {th }}$ days (1.74\%). We notice that daily and cumulative CFR for COVID-19 will continue to change as far as new confirmed and death cases are reported. Malaysia also recorded medium cumulative CFR value among the neighbouring countries during the time reviewed as shown in Table 2. However, to date, the CFR of SARS-CoV (9.6\%) and MERS-CoV (34.4\%) is higher than that of COVID-19 [39]. At present, the general impact of Covid-19 is higher than that of SARS-CoV and MERS-CoV.

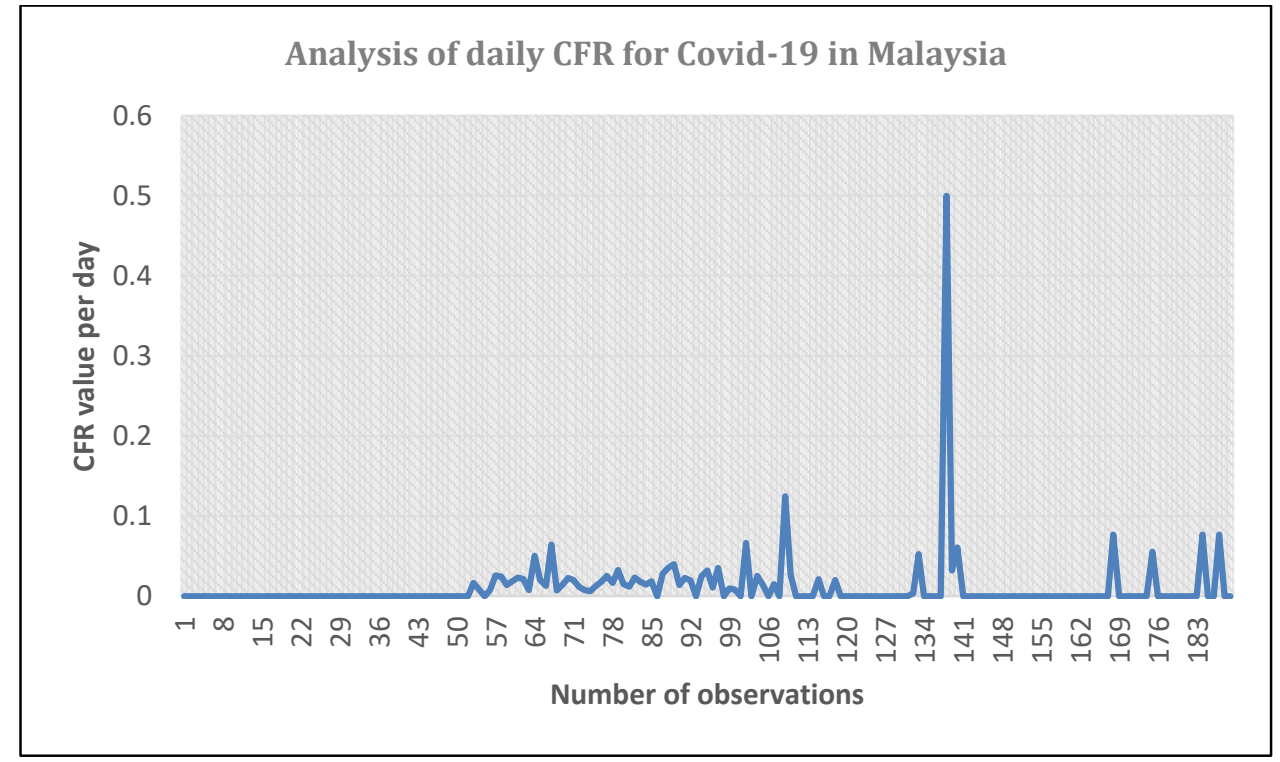

Fig. 3. Daily case fatality ratio in Malaysia 


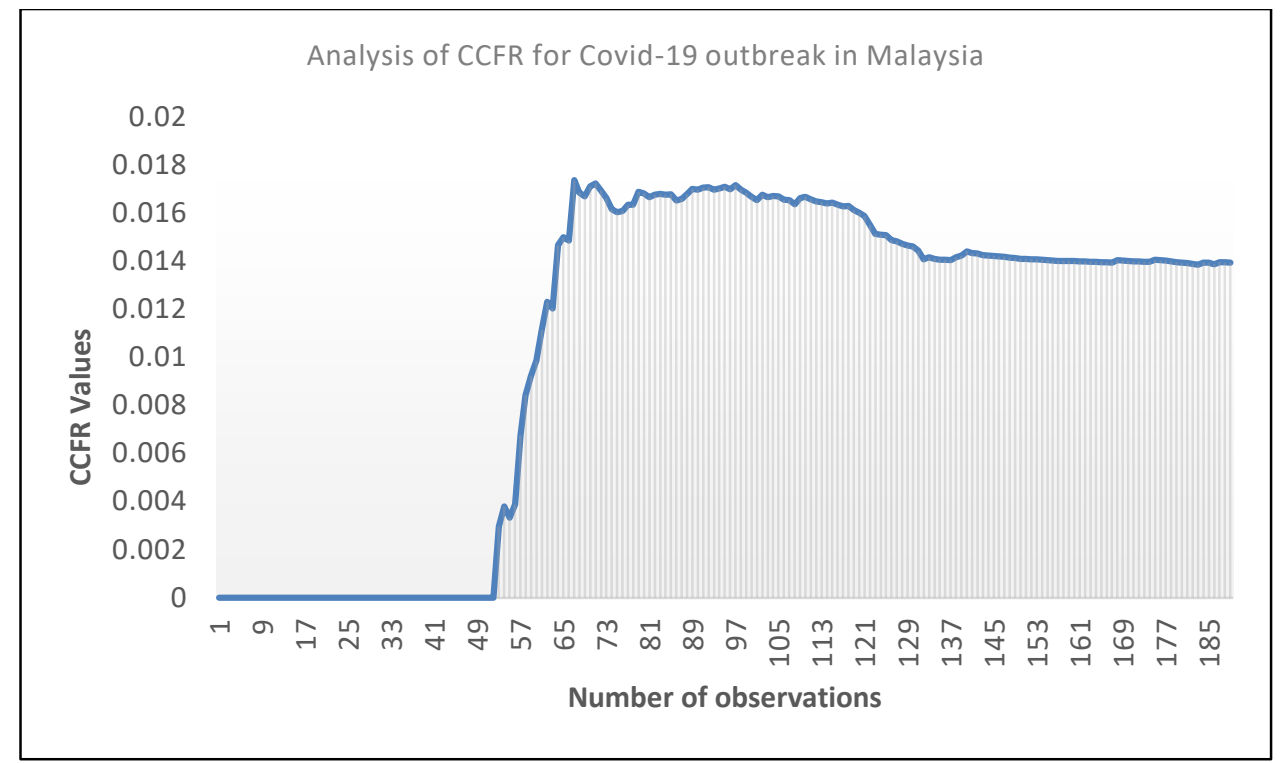

Fig. 4. Cumulative case fatality ratio in Malaysia

Table 2

Comparison of Cumulative CFR among Countries

\begin{tabular}{|c|c|}
\hline Countries & CCFR \\
\hline Malaysia & $1.39 \%$ \\
\hline Singapore & $0.05 \%$ \\
\hline Brunei & $2.13 \%$ \\
\hline Thailand & $1.75 \%$ \\
\hline Indonesia & $4.73 \%$ \\
\hline Myanmar & $1.7 \%$ \\
\hline Philippines & $2.17 \%$ \\
\hline
\end{tabular}

Table 3 shows the deaths cases based on gender, age, and medical condition. The youngest case involves a patient 23 years old while the oldest is 96 years old. From 125 fatality cases, 94 cases (75.2\%) are male while 31 cases (24.8\%) are female. This finding corroborates with the studies that Covid-19 invaded the male population than females. For further analysis, one case of a male patient is excluded because it still under police investigation, and detailed information of the patient was not completed. From Table 4, the mean age for the male is 63.6 while the female is 66.65 which falls under the elderly category. From Table 5 , the result shows that the $p$-value is not significant ( $p$-value $>\alpha$ ). Therefore, not enough evidence to conclude that mean age for males that involve in fatality is greater than female patients.

More than half of the patients fall under the elderly category which is 60 years and more. 87 cases $(70.2 \%)$ involve elderly patients and from this figure, $75.9 \%$ are male while $24.1 \%$ involve females. The fatality rate is high for age 60 and above for male but female of this same age categories is less fatal. This result supports the statement that people of sixty years and above are most affected by COVID-19. From all fatality cases, 92 cases (73.6\%) involve patients with health complications. From this figure, 68 cases $(73.9 \%)$ involve males while 24 cases $(26.1 \%)$ involve females. Patients with health complications such as cardiovascular disease, cancer, diabetes, and chronic respiratory diseases are at high risk. From Table 6, the mean age for the male with health complications is 66.13 while the female is 64.74 . The result from Table 7 shows that the $p$-value is not significant ( $p$-value > $\alpha$ ). Hence, mean age for males that involve in fatality with health complications is greater than female patients. 


\section{Table 3}

Death cases in Malaysia based on gender, age and health condition

\begin{tabular}{|c|c|c|c|c|c|c|c|c|c|c|c|}
\hline \multirow[t]{2}{*}{ Gender } & \multicolumn{10}{|c|}{ Age } & \multirow[t]{2}{*}{ Total } \\
\hline & \multicolumn{2}{|c|}{$<40$} & \multicolumn{2}{|c|}{$40-49$} & \multicolumn{2}{|c|}{$50-59$} & \multicolumn{2}{|c|}{$60-69$} & \multicolumn{2}{|c|}{$\geq 70$} & \\
\hline Male & \multicolumn{2}{|c|}{7} & \multicolumn{2}{|c|}{6} & \multicolumn{2}{|c|}{14} & \multicolumn{2}{|c|}{38} & \multicolumn{2}{|c|}{28} & 93 \\
\hline Female & \multicolumn{2}{|c|}{2} & \multicolumn{2}{|c|}{4} & \multicolumn{2}{|c|}{4} & \multicolumn{2}{|c|}{5} & \multicolumn{2}{|c|}{16} & 31 \\
\hline \multicolumn{11}{|c|}{ Health Complication } & \\
\hline & Yes & No & Yes & No & Yes & No & Yes & No & Yes & No & \\
\hline Male & 3 & 4 & 2 & 4 & 8 & 6 & 32 & 6 & 23 & 5 & 93 \\
\hline Female & 2 & 0 & 3 & 1 & 3 & 1 & 5 & 0 & 11 & 5 & 31 \\
\hline
\end{tabular}

Table 4

Descriptive statistic for fatality cases based on gender

\begin{tabular}{|ccc|c|c|c|}
\hline \multirow{3}{*}{ Age } & & \multicolumn{5}{c|}{ Group Statistics } \\
& Gender & N & Mean & Std. Deviation & Std. Error Mean \\
\cline { 2 - 6 } & Male & 93 & 63.60 & 13.370 & 1.386 \\
\cline { 2 - 6 } & Female & 31 & 66.65 & 17.751 & 3.188 \\
\hline
\end{tabular}

Table 5

Independent samples test for age based on gender

\begin{tabular}{|c|c|c|c|c|c|c|c|c|c|c|}
\hline & & & & & depende & t Sample & Test & & & \\
\hline & & $\begin{array}{c}\text { Levene } \\
\text { for Eq } \\
\text { of Vari }\end{array}$ & $\begin{array}{l}\text { Test } \\
\text { ality } \\
\text { nces }\end{array}$ & & & & test for Equ & ity of Means & & \\
\hline & & & & & & Sig. (2- & Mean & Std. Error & $\begin{array}{r}95 \% \text { Confide } \\
\text { of the Dif }\end{array}$ & $\begin{array}{l}\text { e Interval } \\
\text { rence }\end{array}$ \\
\hline & & $\mathrm{F}$ & Sig. & $\mathrm{t}$ & $d f$ & tailed) & Difference & Difference & Lower & Upper \\
\hline Age & $\begin{array}{l}\text { Equal variances } \\
\text { assumed }\end{array}$ & 5.245 & .024 & -1.007 & 122 & .316 & -3.043 & 3.022 & -9.025 & 2.939 \\
\hline & $\begin{array}{l}\text { Equal variances } \\
\text { not assumed }\end{array}$ & & & -.875 & 41.930 & .386 & -3.043 & 3.477 & -10.059 & 3.973 \\
\hline
\end{tabular}

\section{Table 6}

Descriptive statistic for fatality cases among patient with health complication based on gender

\begin{tabular}{|c|c|c|c|c|c|}
\hline \multicolumn{6}{|c|}{ Group Statistics } \\
\hline & Gender & $\mathrm{N}$ & Mean & Std. Deviation & Std. Error Mean \\
\hline \multirow[t]{2}{*}{ Age } & Male & 69 & 66.13 & 12.498 & 1.505 \\
\hline & Female & 23 & 64.74 & 17.525 & 3.654 \\
\hline
\end{tabular}

Table 7

Independent samples test for age of patient with health complication based on gender

\begin{tabular}{|c|c|c|c|c|c|c|c|c|c|c|}
\hline & & & & Indep & endent & amples & Test & & & \\
\hline & & $\begin{array}{l}\text { Levene } \\
\text { for Equ } \\
\text { Varia }\end{array}$ & $\begin{array}{l}\text { Test } \\
\text { ity of } \\
\text { ces }\end{array}$ & & & & -test for Equ & ality of Mea & & \\
\hline & & & & & & Sig. (2- & Mean & Std. Error & $\begin{array}{l}95 \% \text { Confic } \\
\text { of the }\end{array}$ & $\begin{array}{l}\text { ce Interval } \\
\text { erence }\end{array}$ \\
\hline & & $\mathrm{F}$ & Sig. & $\mathrm{t}$ & $\mathrm{df}$ & tailed) & Difference & Difference & Lower & Upper \\
\hline Age & $\begin{array}{l}\text { Equal variances } \\
\text { assumed }\end{array}$ & 4.838 & .030 & .416 & 90 & .679 & 1.391 & 3.346 & -5.256 & 8.038 \\
\hline & $\begin{array}{l}\text { Equal variances } \\
\text { not assumed }\end{array}$ & & & .352 & 29.815 & .727 & 1.391 & 3.952 & -6.681 & 9.464 \\
\hline
\end{tabular}




\section{Conclusions}

The daily and cumulative case fatality ratio (CFR) for Malaysia was investigated. The study revealed that the cumulative CFR for Malaysia for the period under discussion is $1.39 \%$ while the global CFR is $3.88 \%$ as of $31^{\text {st }}$ July 2020 . The study showed that COVID-19 invaded the male population than females since $75.2 \%$ of fatality cases involved males while only $24.8 \%$ cases are female. The hypothesis test also concluded that the mean age for males that involve in fatality is less than female. This study revealed that people of sixty years and above and people with health complications are at high risk and mostly affected by COVID-19.

As of now, there is no existing treatment or vaccine that is specifically effective towards COVID19 as a cure or a preventive measure. Scientists around the globe are working hard on such objectives. Until then, non-pharmaceutical interventions (NPI) are some of the important strategies to break and to flatten the epidemic curve. The public must embrace social distancing and facemask as the new normal. COVID-19 shall be remembered as an important pandemic lesson to all the countries in the world. This COVID-19 is not the first global pandemic and it will not be the last.

\section{Acknowledgment}

The authors are thankful to Universiti Utara Malaysia for the support to carry out this research work.

\section{References}

[1] Huang, Chaolin, Yeming Wang, Xingwang Li, Lili Ren, Jianping Zhao, Yi Hu, Li Zhang et al. "Clinical features of patients infected with 2019 novel coronavirus in Wuhan, China." The lancet 395, no. 10223 (2020): 497-506.

[2] CDC. 2019 Novel Coronavirus, Wuhan, China. CDC. Available at https://www.cdc.gov/coronavirus/2019ncov/about/index.html. accessed April 2020.

[3] World Health Organization. Novel Coronavirus (2019-nCoV). Available at https://www.who.int/emergencies/diseases/novel-coronavirus-2019. accessed April 2020.

[4] Wu, Y.C., Chen, C.S. and Chan, Y.J. "The outbreak of COVID-19: An overview." Journal of Chinese Medical Association 83 (2020): 217-220.

[5] Zhu, Na, Dingyu Zhang, Wenling Wang, Xingwang Li, Bo Yang, Jingdong Song, Xiang Zhao et al. "China Novel Coronavirus Investigating and Research Team. A novel coronavirus from patients with pneumonia in China, 2019." N Engl J Med 382, no. 8 (2020): 727-733.

[6] Gallegos, A. WHO Declares Public Health Emergency for Novel Coronavirus. Medscape Medical News. Available at https://www.medscape.com/viewarticle/924596. accessed: April 2020.

[7] Ramzy, A. and McNeil, D.G. W.H.O. Declares Global Emergency as Wuhan Coronavirus Spreads. The New York Times. Available at https://nyti.ms/2RER70M. accessed: April 2020.

[8] The New York Times. Coronavirus Live Updates: W.H.O. Declares Pandemic as Number of Infected Countries Grows. The New York Times. Available at https://www.nytimes.com/2020/03/11/world/coronavirusnews.html\#link-682e5b06. accessed: April, 2020.

[9] Lekhraj Rampal and Liew Boon Seng. "Coronavirus disease (COVID-19) pandemic." Med J Malaysia. 75, no. 2 (2020): 95-97.

[10] Europe now 'epicentre' of COVID-19 pandemic: WHO. Available at: https://www.channelnewsasia.com/news/world/ europenow-epicentre-of-covid-19-coronavirus-pandemic-who12536976?cid=telegram_cna_social_28112017_cna. Accessed April 2020.

[11] World Health Organization. Coronavirus disease 2019 (COVID-19) Situation Report - 193. Available at: https://www.who.int/docs/default-source/coronaviruse/situation-reports/20200731-covid-19-sitrep193.pdf?sfvrsn=42a0221d_4, accessed July 2020.

[12] Ciotti, M., Angeletti, S., Minieri, M., Giovannetti, M., Benvenuto, D., Pascarella. S., et al. "COVID-19 Outbreak: An Overview." Chemotheraphy. (2020): 1-9. DOI: 10.1159/000507423.

[13] Chan, Jasper Fuk-Woo, Shuofeng Yuan, Kin-Hang Kok, Kelvin Kai-Wang To, Hin Chu, Jin Yang, Fanfan Xing et al. "A familial cluster of pneumonia associated with the 2019 novel coronavirus indicating person-to-person transmission: a study of a family cluster." The Lancet 395, no. 10223 (2020): 514-523.

[14] Huang, Chaolin, Yeming Wang, Xingwang Li, Lili Ren, Jianping Zhao, Yi Hu, Li Zhang et al. "Clinical features of patients infected with 2019 novel coronavirus in Wuhan, China." The lancet 395, no. 10223 (2020): 497-506. 
[15] Chen, Nanshan, Min Zhou, Xuan Dong, Jieming Qu, Fengyun Gong, Yang Han, Yang Qiu et al. "Epidemiological and clinical characteristics of 99 cases of 2019 novel coronavirus pneumonia in Wuhan, China: a descriptive study." The Lancet 395, no. 10223 (2020): 507-513.

[16] Li, Qun, Xuhua Guan, Peng Wu, Xiaoye Wang, Lei Zhou, Yeqing Tong, Ruiqi Ren et al. "Early transmission dynamics in Wuhan, China, of novel coronavirus-infected pneumonia." New England Journal of Medicine (2020).

[17] Lauer, S.A., Grantz, K.H., Bi, Q., Jones, F.K, Zheng, Q., Meredith, H.R., et al. "The Incubation Period of Coronavirus Disease 2019 (COVID-19) from Publicly Reported Confirmed Cases: Estimation and Application." Ann Intern Med. 2020 [Epub ahead of print].

[18] Backer, J.A., Klinkenberg, D., and Wallinga, J. "Incubation period of 2019 novel coronavirus (2019-nCoV) infections among travellers from Wuhan, China 20-28 January 2020". Euro Surveill. 25, no.5 (2020): doi: 10.2807/15607917.ES.2020.25.5.2000062.

[19] European Centre for Disease Prevention and Control. Algorithm for the management of contacts of probable or confirmed COVID-19 cases. Available at: https:// www.ecdc.europa.eu/en/publications-data/ algorithmmanagement-contacts-probableor-confirmed-covid-19-cases. accessed April 2020.

[20] Kenyataan Akhbar KPK 25 Januari 2020 - Pengesanan Kes Baharu yang Disahkan Dijangkiti 2019 Novel Coronavirus (2019-nCoV) di Malaysia. Available at: https://kpkesihatan.com/2020/01/25/ kenyataan-akhbar-kpk-25-januari2020-pengesanan-kes-baharu-yangdisahkan-dijangkiti-2019-novel-coronavirus-2019-ncov-di-malaysia/. accessed March 2020.

[21] Kenyataan Akhbar KPK 15 Februari 2020 - Situasi Terkini Jangkitan COVID-19 dan Pengesanan Kes Baharu Ke-22 di Malaysia. Available at: https://kpkesihatan.com/2020/02/15/kenyataanakhbar-kpk-15-februari-2020-situasiterkini-jangkitan-covid-19-danpengesanan-kes-baharu-ke-22-di-malaysia/. accessed March 2020.

[22] Kenyataan Akhbar KPK 27 Februari 2020 - Situasi Terkini Jangkitan Coronavirus Disease (COVID-19) di Malaysia. Available at: https://kpkesihatan.com/2020/02/27/kenyataan-akhbarkpk-27-februari-2020-situasi-terkinijangkitan-coronavirus-disease-covid19-di-malaysia/. accessed March 2020.

[23] Kenyataan Akhbar YBMK 17 Mac 2020 - Situasi Semasa Jangkitan Penyakit Coronavirus 2019 (COVID-19) di Malaysia. Available at: https://kpkesihatan.com/2020/03/17/kenyataan-akhbarybmk-17-mac-2020-situasisemasa-jangkitan-penyakit-coronavirus-2019covid-19-di-malaysia/. accessed March 2020.

[24] Kenyataan Akhbar YBMK 18 Mac 2020 - Situasi Semasa Jangkitan Penyakit Coronavirus 2019 (COVID-19) di Malaysia. Available at: https://kpkesihatan.com/2020/03/18/kenyataan-akhbarybmk-18-mac-2020-situasisemasa-jangkitan-penyakit-coronavirus-2019covid-19-di-malaysia/. accessed March 2020.

[25] The Prime Minister's Special Message on Covid-19 -16 March 2020 . Available at: https://www.pmo.gov.my/2020/03/ perutusan-khas-yab-perdana-menteri-mengenai-covid-19-16-mac-2020/. accessed March 2020.

[26] Koya, Z. MCO extended until April 28, PM announces (updated). Available at: https://www.thestar.com.my/news/nation/2020/04/10/mco-extended-until-april-28-pm-announces. accessed April 2020.

[27] Povera, A. and Harun, H.N. MCO Phase 4 from April 29 to May 12 . Available at: https://www.nst.com.my/news/nation/2020/04/586998/mco-phase-4-april-29-may-12. accessed April 2020.

[28] Kenyataan Akhbar KPK 29 April 2020 - Situasi Semasa Jangkitan Penyakit Coronavirus 2019 (COVID-19) di Malaysia. Available at: https://kpkesihatan.com/2020/07/31/kenyataan-akhbar-kpk-31-julai-2020-situasi-semasajangkitan-penyakit-coronavirus-2019-covid-19-di-malaysia/. accessed July 2020.

[29] World Health Organization. Coronavirus disease 2019 (COVID-19) Situation Report - 41. Available at: https://www.who.int/docs/default-source/coronaviruse/situation-reports/20200301-sitrep-41-covid19.pdf?sfvrsn=6768306d_2, accessed April 2020.

[30] HHP Kluge. Statement - Older people are at highest risk from COVID-19, but all must act to prevent community spread. Available at: http://www.euro.who.int/en/health-topics/health-emergencies/coronavirus-covid19/statements/statement-older-people-are-at-highest-risk-from-covid-19,-but-all-must-act-to-preventcommunity-spread. Accessed April 2020.

[31] World Health Organization. Ageing and health. Available at: https://www.who.int/news-room/factsheets/detail/ageing-and-health, accessed April 2020.

[32] European center for disease prevention and control. Novel coronavirus disease 2019(covid-19) pandemic; increased transmission in the EU/EEA and the UK, sixth update, $12^{\text {th }}$ March 2020, Stockholm; Rapid Assessment,128.

[33] Adler, S.E., Why coronavirus hit older adults hardest. AARP 2020.

[34] Shim, E., Tariq, A., Choi, W., Lee, Y. and Chowell, G." Transmission potential and severity of covid-19 in South Korea." International Journal of Infectious Diseases, $93 \quad$ (2020): 339:344. https://doi.org/10.1016/j.ijd.2020.03.031. 
[35] Portal Rasmi Kementerian Kesihatan Malaysia. Available at: http://www.moh.gov.my. accessed July 2020.

[36] From the Desk of the Director-General of Health Malaysia. Available at: https://kpkesihatan.com/. accessed July 2020.

[37] COVID-19 Outbreak Live Updates. Available at: https://www.outbreak.my/. accessed July 2020.

[38] Covid-19 in Malaysia. Available at: newslab.malaysiakini.com. accessed July 2020.

[39] Okwonu, F.Z., Abdelsalam, M.K, Farhan Basheer, M., Ahad, N.A, Arunaye, F.I, \& Zahayu, M.Y. (2020). Review of COVID-19 112 days of global exploration in 212 countries/territories outside China. In Press 